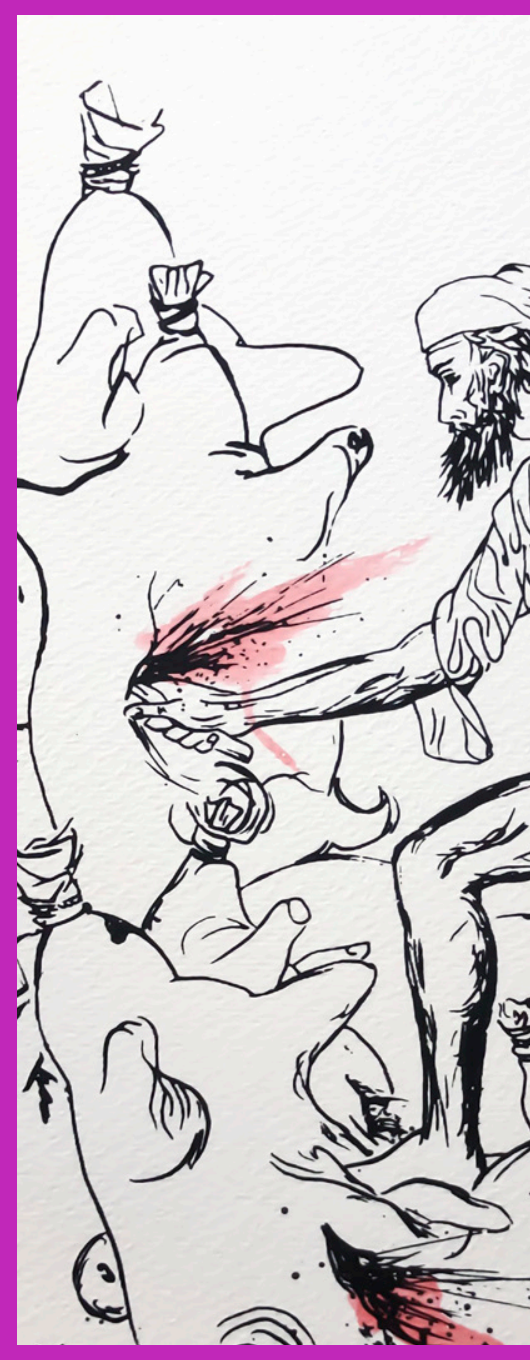




\section{Javier García-Luengo Manchado I María Dolores García Ramos I José Miguel Mu- ñoz Jiménez I Victoria Sánchez Mellado | Raúl Zhingre}
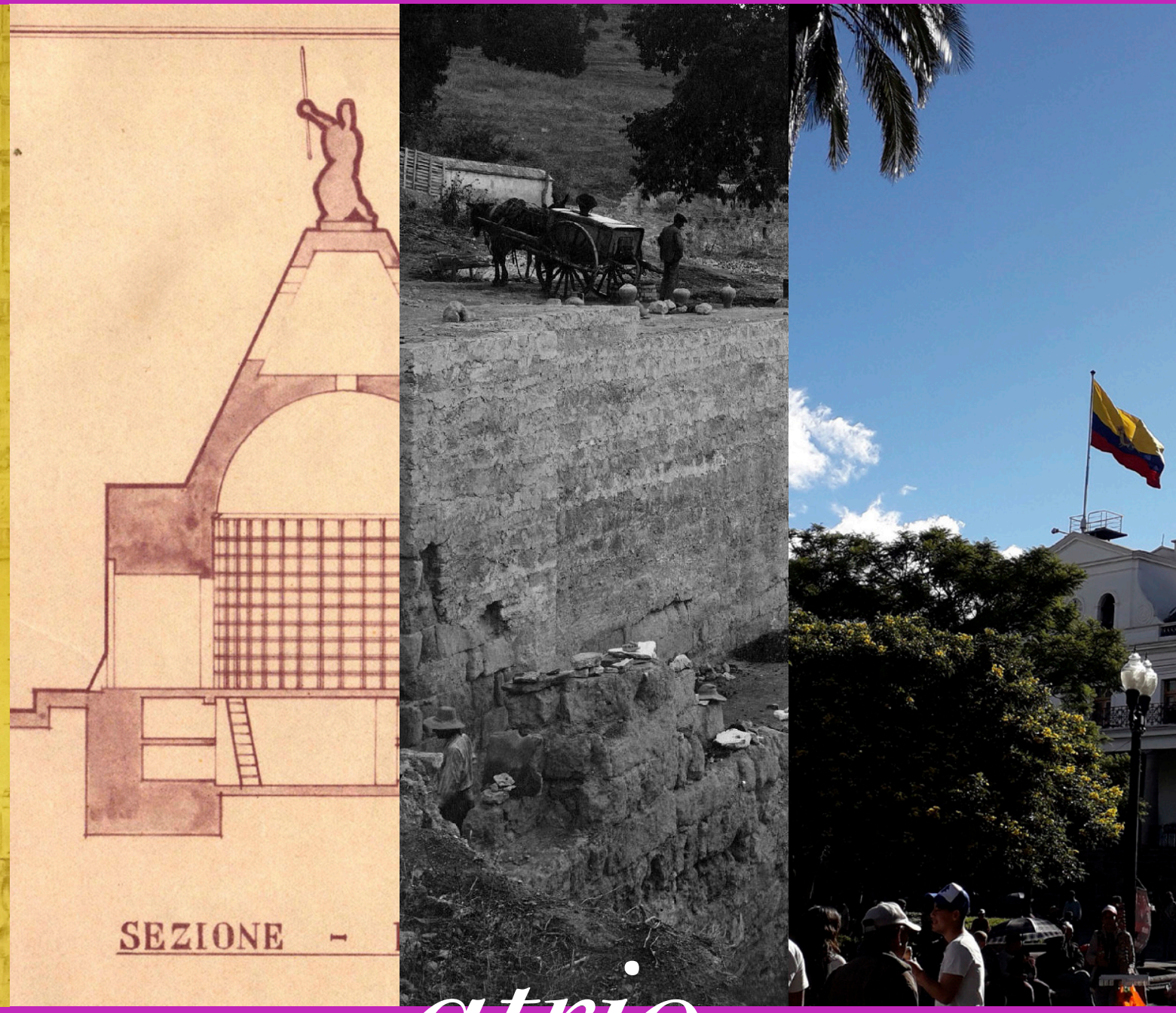

contemporánea 


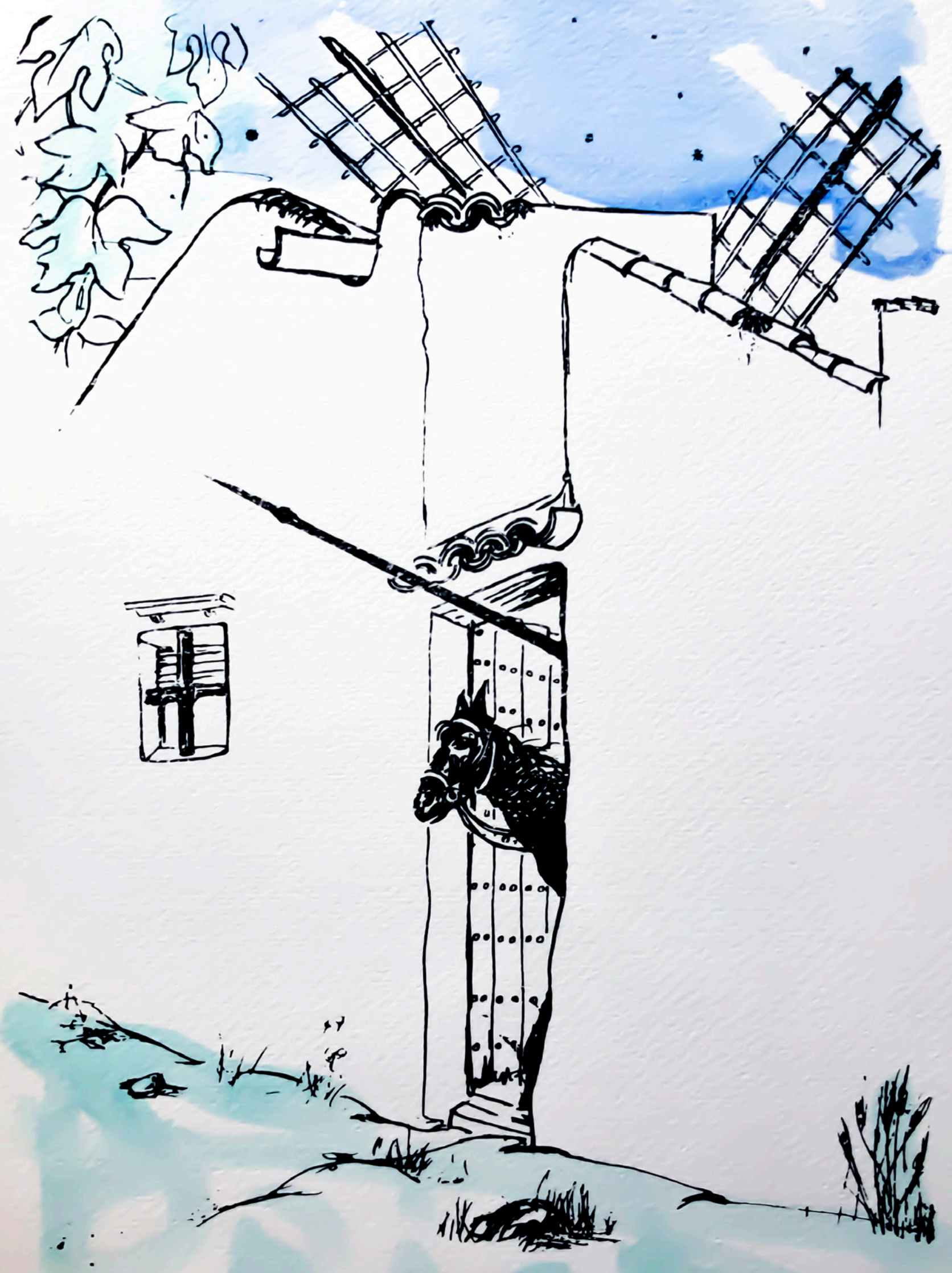

Fig. 1. Gregorio Prieto: La del Alba sería... (1963), litografía, Fundación Gregorio Prieto. 


\title{
Gregorio Prieto: Cervantes y Don Quijote como experiencia estética
}

Gregorio Prieto: Cervantes and Don Quixote as an aesthetic experience

\author{
Javier García-Luengo Manchado \\ Universidad Isabel I de Castilla, Burgos, Espańa \\ javier.garcia.luengo@ui1.es \\ https://orcid.org/0000-0001-5044-5671
}

\section{Resumen}

Cervantes y los temas cervantinos constituyen un lugar común en el amplio quehacer de Gregorio Prieto, uno de los pintores más significativos de la Generación del 27. Tal inquietud, si bien es detectable ya en sus primeros trabajos, se agudizó durante la prolongada estancia de Prieto en Inglaterra, entre 1937 y 1948. Desde este momento, Cervantes en general y Don Quijote en particular canalizarían el anhelo del creador manchego por su añorada tierra. El objetivo pues del presente artículo es contextualizar estética y artísticamente la edición ilustrada de El Quijote por Gregorio Prieto, una de sus creaciones más conocidas. Palabras clave: Gregorio Prieto; Cervantes; Don Quijote: La Mancha.

\section{Abstract}

Cervantes and the Cervantine themes are a common element in the extensive works of Gregorio Prieto, one of the most significant painters of the Generation of '27. While his affinity can be detected since his earliest works, what appears certain is that Prieto's extended stay in London, from 1937-1948, only helped increase this interest, since the Manchegan creator channeled his desire for his longed for homeland through Cervantes, and the Quixote in particular. This article aims to set Gregorio Prieto's Illustrated Quixote, one of his most beloved creations, in a wider context.

Keywords: Gregorio Prieto; Cervantes; Don Quixote; La Mancha. 
Antes de abordar la experiencia estética e iconográfica de la obra y la figura de Cervantes en la trayectoria personal y artística de Gregorio Prieto, es necesario contextualizar brevemente la amplia producción de este artista, para así entender cómo surge y se desarrolla ese peculiar fervor del pintor valdepeñero por Cervantes y, muy particularmente, por el más destacado de sus personajes: Don Quijote ${ }^{1}$.

Gregorio Prieto, viajero infatigable, que residió por largos periodos en Londres, Roma o París, nació en la localidad ciudadrealeña de Valdepeñas en 1897, donde vería por última vez la luz en 1992. Desde su infancia, La Mancha como experiencia estética marcó profundamente a nuestro artista. A pesar de que siendo un niño de apenas ocho años abandonase junto con su familia la ciudad que le vio nacer para establecerse en Madrid, aquella llanura, aquel amplio horizonte y aquellas casas encaladas en blanco y añil, quedaron para siempre grabadas en la retina de quien tan tempranamente sintió una gran vocación pictórica. De hecho, con diecisiete años Gregorio Prieto consigue, contra la voluntad de su padre, ingresar en la Escuela Especial de Pintura Escultura y Grabado de Madrid, ampuloso nombre oficial de la que se seguía conociendo popularmente como Escuela de San Fernando.

Precisamente, es en su etapa estudiantil, desarrollada entre 1915 y 1922, cuando se produce uno de los primeros contactos de Prieto con Cervantes y con El Quijote. Una de las asignaturas por la que más entusiasmo sintió el creador valdepeñero, como el resto de compañeros de promoción, entre quienes podemos destacar a Joaquín Valverde, Timoteo Pérez Rubio, y a la que fuera esposa de este último, Rosa Chacel, fue la asignatura de Paisaje. Ello no es extraño, en una institución anquilosada todavía en los modelos estéticos y de aprendizaje decimonónicos, dicha asignatura se había renovado paulatinamente al hilo de la influencia impresionista. De ahí, por ejemplo, que la Cátedra de Paisaje inaugurase la Residencia de Paisajistas de El Paular, experiencia pionera a la hora de aglutinar una auténtica colonia de creadores que conviviesen directamente con la naturaleza, con el fin de recrearla a través de sus pinceles en toda su inmediatez. La promoción del pintor veintisietista fue la encargada de inaugurar este pensionado ${ }^{2}$.

El impulso para tal renovación vino de la mano de quien por entonces ocupaba la Cátedra de esta materia: Antonio Muñoz Degrain. Justo en los años en los que Muñoz Degrain impartió la referida asignatura a la promoción del pintor manchego, el artista valenciano estaba trabajando en uno de sus conjuntos pictóricos más notables. Se trata de la serie que, en palabras de Manuel Monsonís, Degrain dedicó a las "aventuras de Don

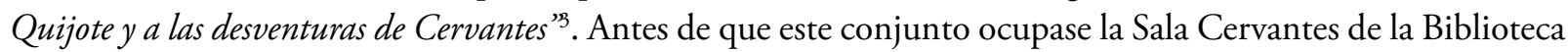
Nacional, en la cual aun hoy la podemos admirar, la serie fue expuesta en la Real Academia de Bellas Artes de San Fernando en junio de 1918, donde Gregorio Prieto la estudió.

La gran aportación de estos monumentales óleos es que con ellos Muñoz Degrain inauguraba una nueva tendencia a la hora de interpretar los lances de Don Alonso Quijano, dejando a un lado la imposición dimanada de la tradición romántica, a favor de una exégesis mucho más original gracias al empleo del divisionismo de corte postimpresionista, amén del ambiente que Muñoz Degrain acuña en todos estos pasajes,

1. Deseo manifestar mi gratitud a la Fundación Gregorio Prieto por su apoyo para la realización de este artículo, así como por su autorización para la reproducción de las imágenes que aquí se incluyen.

2. GARCÍA-LUENGO, Javier, "La primera promoción de la residencia de paisajistas de El Paular", Boletín de la Real Academia de Bellas Artes de la Purísima Concepción de Valladolid, n. ${ }^{\circ}$ 47, 2012, págs. 115-124.

3. MONSONÍS MONFORT, Manuel, "La Sala Cervantes de la Biblioteca Nacional", Ars Longa, n. 13, 2004, págs. 53-55. 


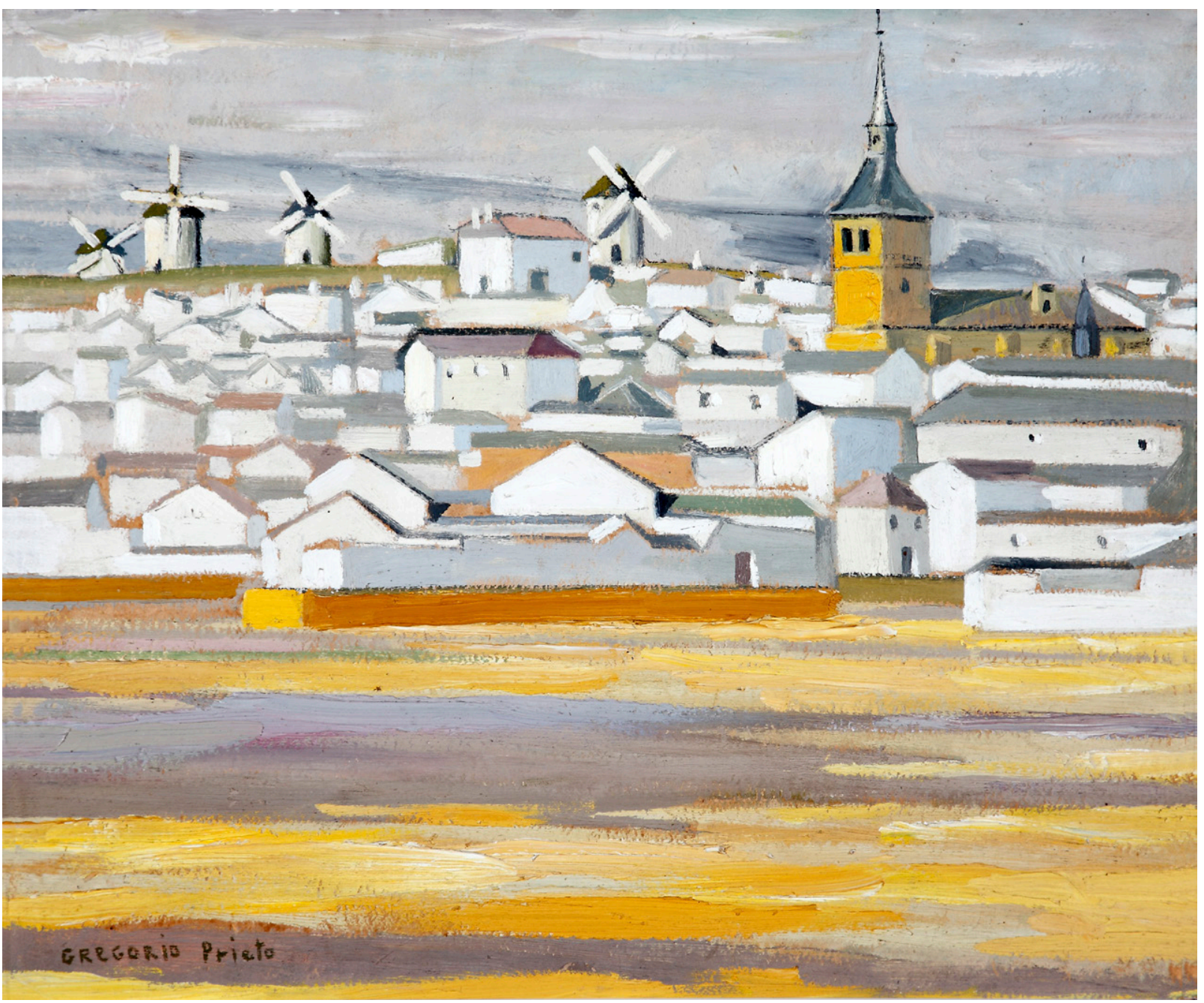

Fig. 2. Gregorio Prieto: Paisaje de Campo de Criptana (h. 1926-1928), óleo sobre lienzo, Fundación Gregorio Prieto.

de clara progenie simbolista. Este marcado acento personal no caerá en saco roto cuando Gregorio Prieto, como otros creadores del siglo XX, tenga que abordar semejante iconografía.

Junto a lo expuesto, el acercamiento del artista a Cervantes vino también por estos años a través de la propia figura de Don Quijote, del mismo modo que la pasión por tal personaje le llegaría mediante su relación con el paisaje manchego. En efecto, en la ética dimanada de la estética de aquella llanura y de aquellos pueblos, nuestro artista atisbó algunos de los rasgos más sobresalientes del Caballero de la Triste Figura: su nobleza, su forma personal de entender el mundo, así como aquellas visiones e imaginación tan absolutamente surreales, con las que tanto comulgaría Prieto.

A este respecto, el propio pintor describió el entronque del paisaje manchego con los personajes cervantinos: 
"Quien haya vivido intensamente La Mancha comprende que sólo en estas tierras desoladas y duras, donde el alma encuentra un horizonte propicio para la expansión, se han podido dar hazañas tan prodigiosas como las de Don Quijote, nombre para siempre gloriosamente unido al de la tierra que le dio la vida. Porque Don Quijote y Sancho como simbolo de lo imaginativo y lo real, formando un haz y un envés de encontradas cualidades, son antes que nada facetas del carácter manchego que, por un asombro milagroso, sabe armonizar perfectamente lo genial con lo discreto, la fantasía con el pan de cada día. Los dos héroes cervantinos

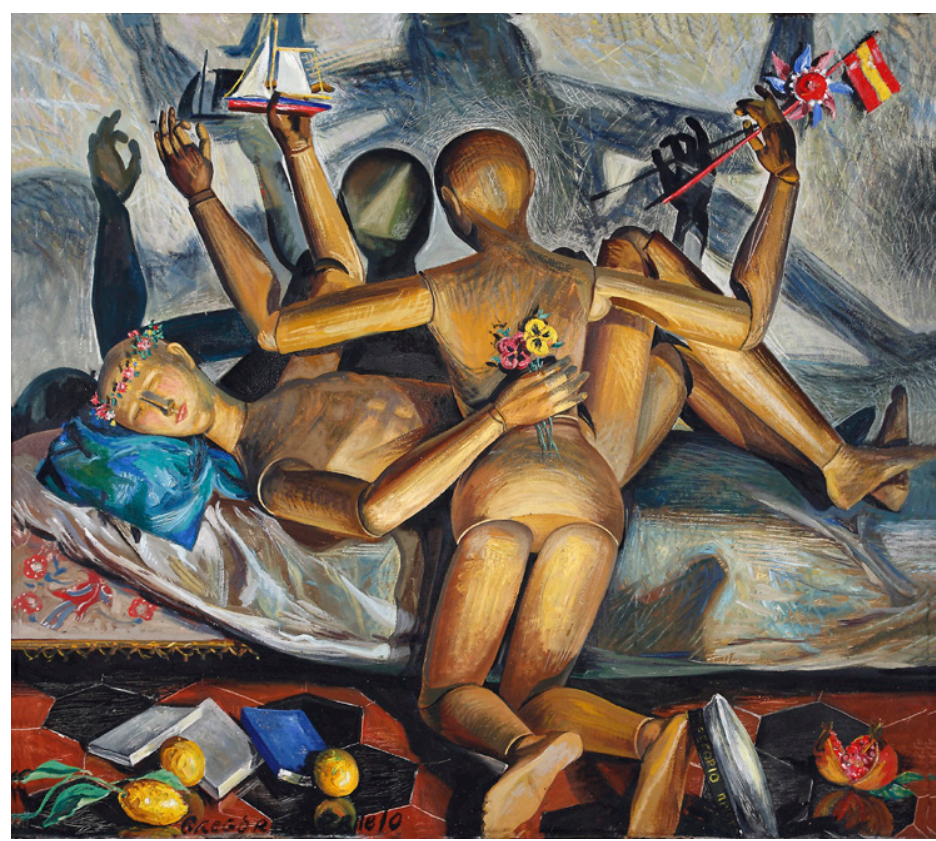

Fig. 3. Gregorio Prieto: Los maniquíes (h. 1931-1935), óleo sobre lienzo, Fundación Gregorio Prieto.

participan de los primarios elementos que componen esta tierra. La sobria sencillez y la patente realidad se coronan con un halo impalpable de poesía que ennoblece" ${ }^{\text {". }}$.

Según se ha apuntado, La Mancha constituyó todo un sino en el quehacer artístico de Gregorio Prieto; y ciertamente aquel terruño, al que siempre le unió un recíproco e inexorable cariño, se convertiría en clave para entender el giro hacia la modernidad del valdepeñero. De hecho, Prieto, como otros jóvenes pintores anhelantes de renovación, quedó conmovido por la exposición que Daniel Vázquez Díaz realizó, junto a su esposa la escultora Eva Aggerholm, en el Palacio de Bibliotecas y Museos de Madrid en $1921^{5}$. Desde entonces, la vanguardia madrileńa trabajaría en torno a un neocubismo proclive a sintetizar la realidad. El pintor objeto de este artículo fue abanderado en esta tendencia, que reforzó durante 1925, cuando en calidad de becario de la Junta de Ampliación de Estudios residió en París, ese París, por cierto, que apenas acababa de asistir al nacimiento del surrealismo.

No obstante, antes de la referida estadía en la capital francesa, el valdepeñero realizó dos importantes viajes a su tierra manchega. El primero de ellos en 1922, con motivo de la invitación del Ayuntamiento de Valdepeñas para homenajearle por la tercera medalla obtenida en la Exposición Nacional de Bellas Artes de ese mismo año ${ }^{6}$ y el segundo en septiembre de 1924, poco antes de marchar a París. En esta ocasión, Prieto aprovechó para recorrer algunas de las localidades más significativas de la ruta del Quijote, como Ruidera, donde se sitúa la aventura de la Cueva de Montesinos; o Campo de Criptana, entre cuyos molinos tradicionalmente se ha querido ubicar la lucha del célebre Hidalgo contra los gigantes aspados. Fue entonces,

4. PRIETO MUÑOZ, Gregorio, Molinos, Madrid, Editora Nacional, 1974, pág. 24.

5. ALBERTI MERELLO, Rafael, La arboleda perdida. Memorias, Barcelona, Seix Barral, 1975, pág. 130.

6. ALBI, M., "Valdepeñas y sus hijos predilectos", El Sol, 22-IX-1922; ANÓNIMO, "Una exposición de pintura", La Libertad, 9-IX-1922; ANÓNIMO, "Valdepeñas y Gregorio Prieto", El Liberal, 13-IX-1922. 
durante sendos viajes a su región de origen, cuando Prieto consideró que en tales pueblos y en aquella meseta residía la modernidad que tanto anhelaba: la brillantez lumínica que otorga esa rotundidad a las formas o las aristas de los paredones y de las torres de sus destartaladas iglesias, sirvieron de inspiración para que el artista valdepeñero se convirtiese en un referente de la vanguardia.

En este sentido, el protagonista de este artículo se inserta en los postulados de la Generación del 27, Generación de la que forma parte no sólo por la gran amistad que mantuvo con García Lorca, Luis Cernuda o Vicente Aleixandre, por citar solo unos ejemplos, sino, y esto es lo importante, porque el pintor participó de sus mismos postulados estéticos. Uno de ellos era encontrar la modernidad en la tradición. Gregorio Prieto hallará la renovación pictórica en La Mancha y la vanguardia ideológica en el personaje de Don Quijote.

Gregorio Prieto se convierte ya por antonomasia en el pintor de la tierra del Caballero de la Triste Figura, de esa visión vanguardista de La Mancha. Así es reconocido no sólo en España sino fuera de ella, tal como sucedió en la primera exposición individual que realizó en el extranjero, concretamente en La Grande Maison de Blanc de París en 1926, o como en la exhibición que se llevó a cabo en junio de 1928 en el Palacio de Bibliotecas y Museos de Madrid7, muestras ambas donde había un capítulo específico dedicado a La Mancha. Desde entonces, la crítica enlazó inexorablemente el nombre de Prieto con el de Cervantes y el de Don Quijote.

Vano sería prolongar esta contextualización de nuestro pintor respecto a La Mancha, en tanto en cuanto, según veremos, tal paisaje y referencia cultural se convertirían en su ulterior trayectoria en todo un símbolo, en una metáfora de anhelo y añoranza en la lejanía. Es curioso anotar, no obstante, cómo durante el pensionado de Gregorio Prieto en la Academia de Espańa en Roma, efectuado entre 1928 y 1933, momento en que su arte se vincula plenamente con la estética de Valori plastici, el Novecento y, por supuesto, con el surrealismo, Prieto seguirá teniendo muy presente la tierra de Don Quijote. De hecho, Prieto siempre alardearía de cierto quijotismo. Así, en esta época de maniquís y de marineros, bien se pueden poner en la boca del artista aquellas palabras otrora pronunciadas por Don Alonso Quijano: "Caballero soy armado, que corre el mundo para desfacer agravios y enderezar entuertos". En efecto, el creador veintisietista, sin más armas que las de sus pinceles, se dio a librar batallas en pro de aquellas causas que entendía nobles y justas, tan dispares como la reconstrucción de los molinos de viento, la recuperación de Zurbarán, la exaltación de la escultura ibérica, la canonización de Isabel la Católica o la donación de toda su obra a España y para ello, como el Ingenioso Hidalgo, nuestro pintor surcará reinos, señoríos, mares y tierras.

Sabido es que la estancia en la Academia de Espańa en Roma obligaba también a viajar por Europa. Pocos becarios como nuestro autor aprovecharon con tanta intensidad tal legalismo, recorriendo Francia, Noruega, Alemania, Austria, llegando incluso al Círculo Polar para contemplar sus noches blancas. Pero de todos aquellos viajes el más importante fue el realizado a Grecia y a las islas del Egeo, en cuyo paisaje el Prieto halló un paralelismo y revivificación del manchego, por ello no es extraño que en sus posteriores exposiciones las obras dedicadas a La Mancha y a Grecia se aglutinasen en un mismo capítulo.

Así las cosas y pasando el tiempo, a Gregorio Prieto, como a tantos y tantos españoles, le tocó sufrir las consecuencias de la Guerra Civil, que en sus primeros momentos vivió en Madrid. Sin embargo,

7. Exposición Gregorio Prieto, Madrid, Palacio de Bibliotecas y Museos, 1928. 
gracias a los contactos efectuados durante una estancia llevada a cabo en Inglaterra pocos meses antes, pudo regresar a Gran Bretańa en 1937, donde residió prácticamente hasta 1950, cuando se instale de nuevo en la capital de España.

Será precisamente en su etapa inglesa cuando con más intensidad Gregorio Prieto se acerque a la obra y a la figura de Cervantes. Ello se debe a dos motivos esenciales. En primer lugar a los encargos que recibirá, no olvidemos que en Inglaterra había una importante colonia de exiliados españoles, buena parte de ellos intelectuales vinculados al mundo de la universidad y a la Institución Libre de Enseñanza. Recordemos, cómo no, a sus buenos amigos Alberto Jiménez Fraud, Natalia de Cossío, Arturo Duperier, el doctor Trueta, Luis Cernuda o Martínez Nadal. Gregorio Prieto se insertó en esta comunidad intelectual y fue en este contexto donde surgirán esos trabajos tendentes a la difusión de la cultura hispana en el medio británico, para ello qué mejor hacerlo sino a través de una de nuestras figuras más internacionales y tan admiradas en la legendaria Albión, como es Cervantes y, por supuesto, su Quijote.

Pero junto a lo expuesto hay otro hecho. Cervantes fue un personaje que a estas alturas ya había conquistado absolutamente a Gregorio Prieto, tanto por su valor literario como también por el mito que de él llegó a fabricar el propio pintor, mito basado, por un lado, en la identificación de Cervantes como esencia de lo español en general y de lo manchego en particular. Pensemos que Gregorio vivirá casi diez años alejado de España y la añoranza se iría haciendo cada vez más acuciante, de suerte que cualquier motivo será bueno para loar a su tierra hispana a través de exposiciones, libros, conferencias, etcétera. La figura de Cervantes, de alguna manera, por lo dicho, aglutinaría todos estos sentimientos y emociones.

Junto a lo argüido, Gregorio Prieto convertirá al autor de La Galatea en auténtico icono respecto al concepto de artista maldito. El hecho de su encarcelamiento, a pesar de lo cual escribió el Quijote, fue motivo de entusiasmo para nuestro artista, razón por la cual, Prieto participaría siempre activamente en todo aquello que pudiera homenajear y divulgar la obra y la persona del insigne escritor.

De esta guisa, el pintor manchego colaboró fervorosamente en los actos que a propósito del cuarto centenario del nacimiento de Miguel de Cervantes se llevaron a cabo en Inglaterra. Destaca así su exposición intitulada In commemoration of fourth centenary of the birth of Miguel de Cervantes Saavedra, organizada por The Hispanic and Luso-Brazilian Councils en el Canning House de Londres noviembre de 1947, en la cual Gregorio Prieto presentó 25 obras relacionadas con los lugares de La Mancha más relevantes del Quijote ${ }^{8}$. En ella se pudieron contemplar calles, callejuelas y patios de El Toboso o Almagro; junto con otras obras que recreaban lugares concretos donde acaecieron algunas de las hazańas de don Alonso Quijano, como la Venta de Puerto Lápice, la Venta de El Toboso, los Molinos de Campo de Criptana, etc.

Dentro de las múltiples y sorprendentes facetas de Gregorio Prieto, también estaba la radiofónica, pues desde 1944 impartió diferentes conferencias y participó en diversos debates que la BBC retransmitía en su programación exterior dedicada a España, sección que entonces dirigía su buen amigo Rafael Martínez Nadal. El objetivo de tal programación era dar a conocer lo mejor del exilio español en Inglaterra. En la mayor

8. In commemoration of the fourth centenary of the birth of Miguel de Cervantes Saavedra, 1547-1616, Londres, The Hispanic and Luso-Brazilian Councils. Canning House, 1947. 


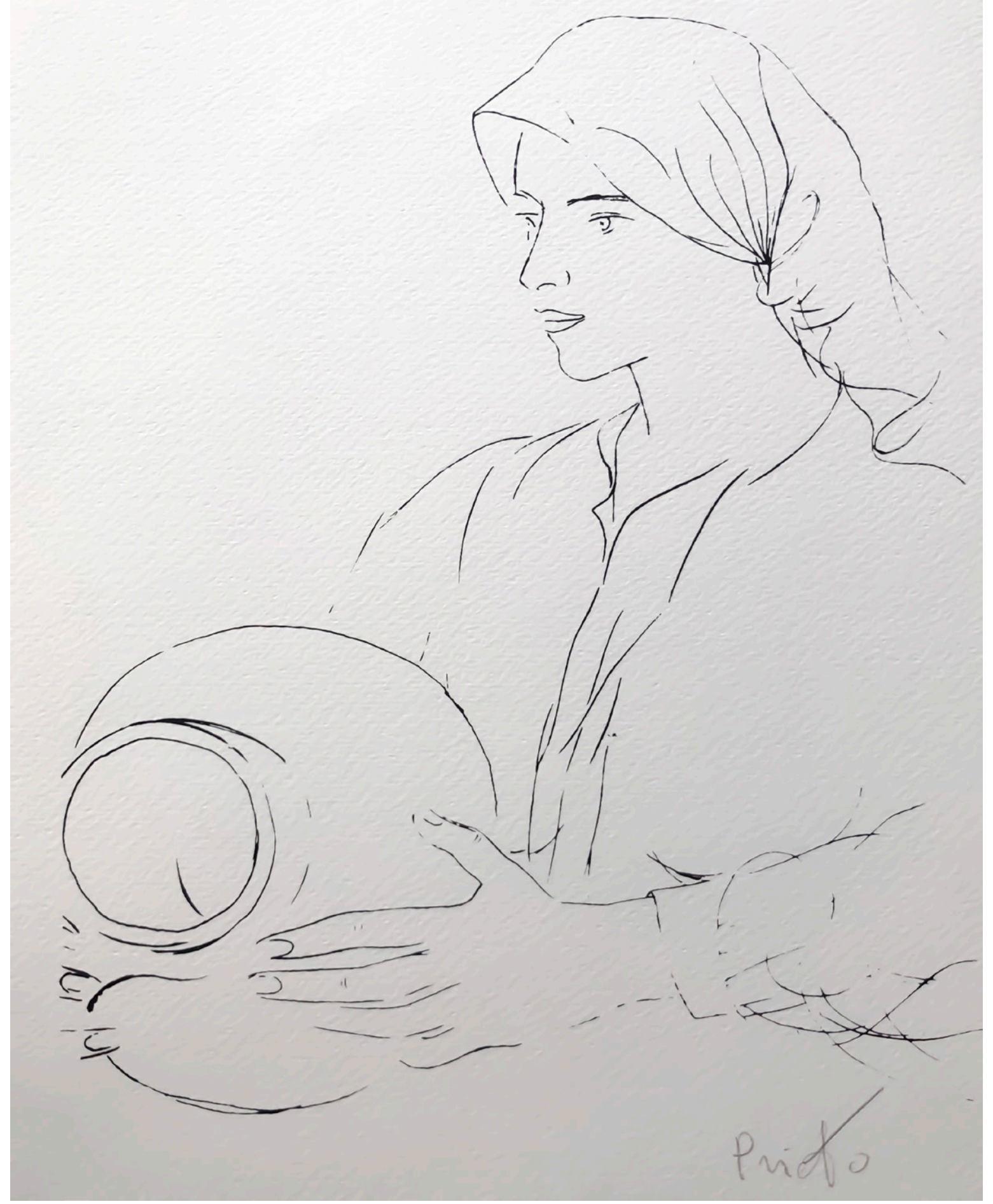

Fig. 4. Gregorio Prieto: Dulcinea, ideal de Don Quijote (1963), litografía, Fundación Gregorio Prieto. 
parte de sus intervenciones, el autor veintisietista se decantó por difundir el conocimiento y la pasión por su querida y anhelada Espańa; y lo haría través de la exaltación de su arte y de su cultura, dedicando charlas a Zurbarán, Murillo, Goya y, por supuesto, a su patria chica, La Mancha9 ${ }^{9}$ La alocución que brindó a esta región se hizo coincidir con el ya citado cuarto centenario del nacimiento de Miguel de Cervantes. La vehemencia del protagonista de este artículo se convirtió en elogios respecto al tema tratado: una especial emoción insufó vida a las palabras pronunciadas con tal motivo. El valdepeñero ligó La Mancha con Cervantes y con las figuras de Don Quijote y de Sancho, sintetizando estos personajes, según el pintor, la quintaesencia de su tierra. El artista manchego, además, quiso unir en su disertación Inglaterra y España a través de los puntos en común existentes entres sus más insignes escritores: Miguel de Cervantes y William Shakespeare. No podemos pasar por alto que Prieto, durante sus años ingleses, dedicó múltiples obras y exposiciones al autor de Hamlet, destacando, por ejemplo, la edición que efectuara de sus célebres Sonetos $^{10}$.

Según se ha dicho, en 1950 Prieto regresaría finalmente a su país tras la prolongada estancia en Reino Unido. A partir de este momento llega a su eclosión lo que otrora fuese anhelo y añoranza, pues recorrería toda la Península recreando y exaltando sus ciudades, su paisaje y su paisanaje; y lo hará con sus pinceles, pero también mediante sus escritos, pues no olvidemos que el artista valdepeñero fue igualmente un pródigo literato.

Es en este contexto donde nuestro pintor va forjando un sueño: la elaboración de una magna edición de El Quijote. Desde ahora trabajaría largamente en una serie de dibujos en torno a esta figura literaria, construyendo así todo un corpus gráfico sobre el que preparar la referida edición ${ }^{11}$.

A tenor de este proceso surgiría la publicación en 1953 del libro titulado La Mancha de Don Quijote $e^{12}$. Esta obra hace las veces de un auténtico cuaderno de viajes a través de los principales enclaves que recorrió Don Alonso Quijano. Tan original camino, Prieto lo efectúa a través de su arte para la pintura y de su arte para las letras, pues cada ilustración está comentada por un breve texto de una alta carga poética, tendente a ensalzar tanto La Mancha como a los personajes cervantinos.

Durante estos años, Prieto, mitómano por antonomasia, peregrinará por los lugares más emblemáticos para el Caballero de la Triste Figura. Además, también conocerá y recreará con su buen hacer las ciudades relacionadas con el propio Cervantes. Así, por ejemplo, en 1951 tuvo la oportunidad de visitar la Casa Museo que el escritor alcalaíno tiene dedicada en Valladolid ${ }^{13}$.

Respecto a los lugares cervantinos, sin duda, nuestro pintor siempre sintió predilección por Argamasilla de Alba, siendo múltiples las actividades que Prieto fomentó en dicha localidad. Destacó su labor en pro de la construcción de un nuevo molino en 1955, al que se le puso por nombre Maeso Pero Pérez. Con motivo de la bendición de este edificio se realizó un acto de exaltación cervantina protagonizado por el poeta Federico Muelas y nuestro pintor. Aquella misma tarde, en la Cueva de Medrano, hubo un coloquio donde Prieto habló

9. Charla de Gregorio Prieto para la BBC titulada La Mancha, 20-10-1947, Archivo de la Fundación Gregorio Prieto, $23 / 5$.

10. SHAKESPEARE, William, The Sonnets, Londres, Grey Walls Press, 1948.

11. FERNÁNDEZ ALBA, J., "Don Quijote de La Mancha, libro de amor", Lanza, 4-VI-1959.

12. PRIETO MUÑOZ, Gregorio, La Mancha de Don Quijote, Madrid, Ínsula, 1953.

13. GARCÍA-LUENGO, Javier, "Gregorio Prieto y Valladolid", Boletín de la Real Academia de Bellas Artes de la Purísima Concepción de Valladolid, n. ${ }^{\circ} 40,2005$, pág. 159. 
de Cervantes, de los molinos y La Mancha ${ }^{14}$. La Cueva de Medrano constituirá para el creador valdepeñero la referencia histórica por excelencia de Cervantes. Por ello, a finales de agosto de 1961, el pintor decidió encerrarse voluntariamente en este lugar, donde según la tradición Cervantes comenzó a escribir su obra más conocida. El fin de tal proeza era el de desagraviar al autor alcalaíno por lo que sufrió en tan singular prisión.

Prieto aprovechó este encierro para redactar el prefacio que luego acompañaría a su edición del Quijote de Biblioteca Nueva ${ }^{15}$. Estos actos que a muchos le parecían extravagantes y oportunistas, sin embargo, eran defendidos por notables intelectuales, como el poeta José Hierro, quien escribió a este propósito:

"Si concibiese ideas fuera de lo común, sin otro propósito que el de llamar la atención, sería un agente publicitario. Pero a Gregorio se le ocurren cosas que estima normales; al exponerlas, le sorprende que los demás las consideren extravagancias. Y al realizarlas, acaban por parecerles a todos naturales. Esto ocurre porque el pintor siempre actúa desinteresada, quijotescamente, que es la mejor manera de persuadir. Más que un Quijote es un Sancho. Lo que sucede es que sus propósitos caen en un mundo desquiciado, lo que hace que parezcan disparates y locuras" ${ }^{16}$.

A lo largo de sucesivas exposiciones efectuadas por toda Espańa en la década de los cincuenta Prieto había ido dando a conocer algunos dibujos elaborados para su sońada edición del Quijote ${ }^{17}$; pero, nuevamente, la Cueva de Medrano de Argamasilla de Alba sería protagonista en este proceso, pues aquí se expuso por vez primera el conjunto completo de estas creaciones. Gregorio Prieto aprovechó una efeméride: en 1863 el impresor Manuel Rivadeneyra trasladó todo su taller desde Madrid a Argamasilla de Alba, con el fin de imprimir una edición del Quijote en el mismo sitio donde Cervantes escribió sus primeros capítulos. Ahora, un siglo después, con el mismo ímpetu romántico, el artista valdepeñero presentaba como adelanto, conmemorando este hecho bibliográfico, algunos dibujos que ilustrarían una nueva edición de las aventuras del Ingenioso Hidalgo. El 24 de abril de 1963 se inauguró esta exhibición, donde se colgaron 17 dibujos que, tiempo después, se encartarían en la edición de mayor monumentalidad que de esta novela se había acometido hasta la fecha ${ }^{18}$.

La crítica ensalzó el auténtico trabajo de arqueología efectuado por el autor a la hora recoger los tipos, ls arquitectura y la flora manchega, lo que unido a algún toque de tintes surrealistas, otorgaba un evidente aire poético y renovado al conjunto ${ }^{19}$.

Pero antes de hablar de la publicación de El Quijote de Prieto, no podemos abandonar esta Cueva de Medrano sin decir que también fue en la prisión cervantina donde aconteció uno de los episodios más emotivos en la biografía del creador valdepeñero, pues finalmente cristalizó una idea que el pintor había anhelado desde sus inicios artísticos. Fruto de su amor al arte, a su arte, y a Espańa, Prieto quería donar todo su legado a su país a través de una fundación que llevara su nombre, con el fin de que todo lo suyo fuese patrimonio de los españoles y que,

14. VILLAREAL, A., "Hoy se inaugura un nuevo molino en La Mancha", Arriba, Madrid, 23-X-1955.

15. ANÓNIMO, "Para desagraviar a Cervantes. El pintor Gregorio Prieto se recluye en la Cueva de Medrano", Informaciones, 28-VIII-1961.

16. HIERRO, José, "Donquijotes, sanmigueles y molinos", El Alcázar, Madrid, IX-1961,

17. VERA CAMACHO, J. P., "El Quijote más monumental lo está haciendo Gregorio Prieto", Dígame, 12-III-1963.

18. GARCÍA MORALES, Justo, Conmemoración de las ediciones del Quijote impresas en Argamasilla de Alba con motivo del primer centenario, Madrid, Ministerio de Educación Nacional, 1963 y ANÓNIMO, "Los actos en homenaje a Cervantes, en Argamasilla de Alba, resultaron brillantísimos", Lanza, 24-IV-1963.

19. ANÓNIMO, "Otra vez Gregorio Prieto", Artes, 23-XII-1963; RABOS BALLESTER, S., "Prieto", ABC, 28-XI-1963; RAMÍREZ DE LUCAS, J., "Prieto", La Estafeta Literaria, 7-XII-1963. 
además, dicha Fundación ayudase a fomentar la promoción de las artes y las letras ${ }^{20}$.

Esta iniciativa tomó forma legal y real el 12 de marzo - día de San Gregorio Magno- de 1968, durante el evento celebrado en esta significativa y simbólica Cueva de Medrano, en el cual se firmó el acta que daba carta de naturaleza a la Fundación Gregorio Prieto. Es revelador para conocer las peculiares inquietudes e intereses del fundador, citar algunas de las personas y de las figuras que aparecen en el capítulo de agradecimientos recogido en el correspondiente acta notarial: "Virgen de la Consolación, Zurbarán, Academia de Bellas Artes de San Fernando, José Miguel Odero, Dama de Elche, José Antonio GarciaNoblejas, Auriga de Delfos, Santa Ysabel de España, Federico García Lorca, Venus de Cirene y mi madrastra Tadea"21. Para celebrar la constitución de la Fundación Gregorio Prieto, se expuso en la Cueva de Medrano la edición príncipe del Quijote de Rivadeneyra, así como las litografías del autor consagradas a este mismo tema ${ }^{22}$.

Un año después de aquel sueño hecho realidad, se cumplió otro, ya que en

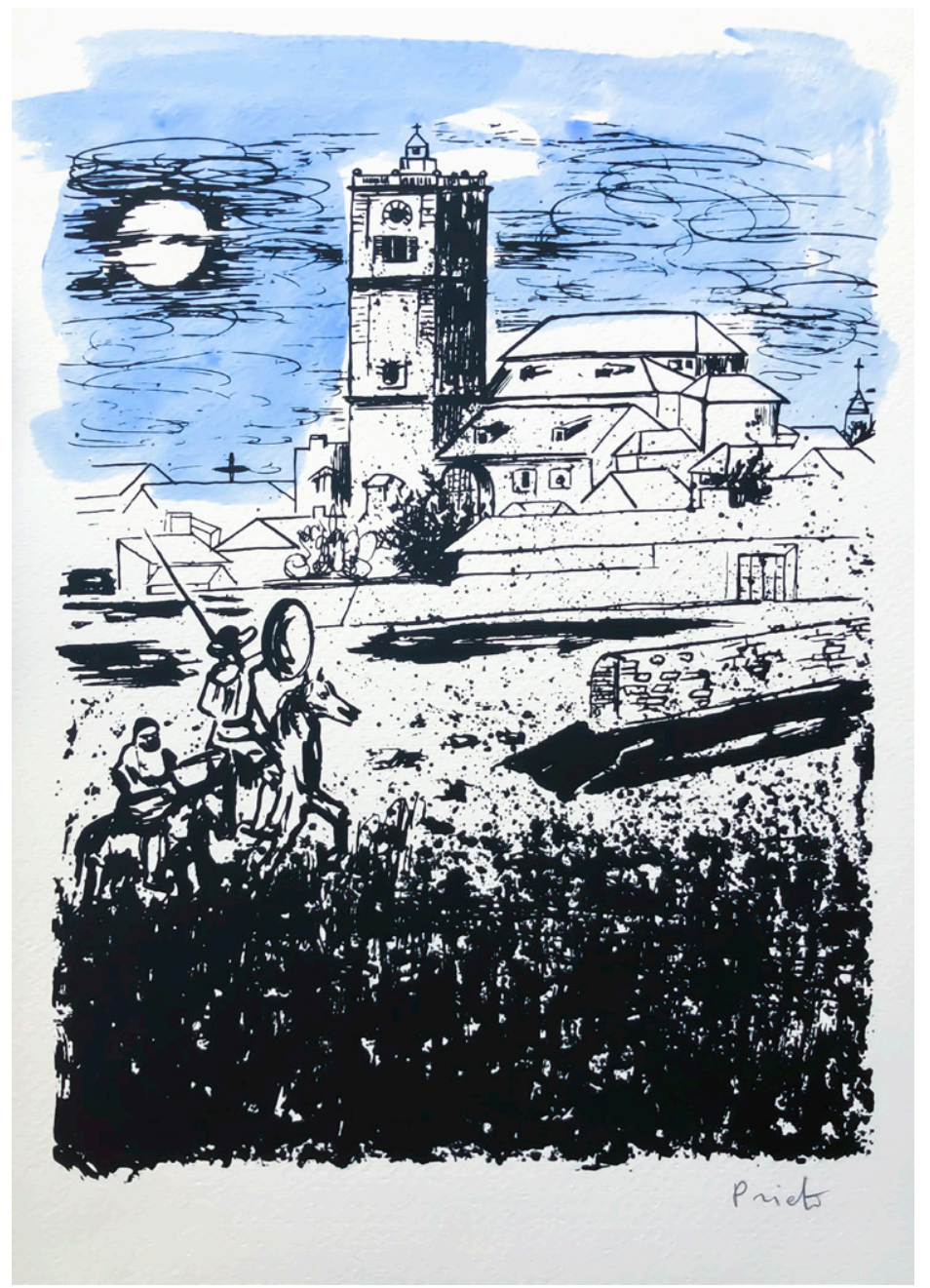

Fig. 5. Gregorio Prieto: Don Quijote, Sancho y la iglesia de El toboso (1963), litografía, Fundación Gregorio Prieto.

\section{Biblioteca Nueva publicó el magno}

Quijote ilustrado por Gregorio Prieto, cuyo éxito hizo que viesen la luz cuatro ediciones más ${ }^{23}$. El creador manchego se encargó de hacer además de las correspondientes estampas, las capitales, colofones y sobrecubiertas,

20. TORRE FRANCO, J., "Se constituye en Madrid la Fundación Gregorio Prieto", El Español, 6-V-1967.

21. Invitación al acto de firma de la escritura constitucional de la Fundación Gregorio Prieto, donde se extracta parte de la misma.

22. ANÓNIMO, "Nueva Fundación", Díez Minutos, 13-III-1968; ARROYO, J. F., "Nace la Fundación Gregorio Prieto", Lanza, 7-III-1968; LÓPEZ, J.,

"La Fundación Gregorio Prieto quedó constituida en Argamasilla de Alba", Ya, 13-III-1968; DE MORA, G., "Ayer se constituyó, en Argamasilla de Alba, la Fundación Gregorio Prieto", La vanguardia, 14-III-1968; TRENAS, J., "El regalo estético de Gregorio Prieto", La Vanguardia Española, 24-III-1968. Argamasilla siempre guardó amor y reconocimiento por todo lo que Gregorio Prieto había hecho por la villa: "Gregorio Prieto, con su perilla lopesca y su bigote borgoñón anda por estas sendas goteando toda su mística para hacer de esta Argamasilla de Azorín y de don Alonso Quijano el Bueno, lugar para volver siempre. [...] A Argamasilla le ha sonado una nueva hora con Gregorio Prieto. Su legado ha sido el otorgamiento más enamorado que se puede hacer a un pueblo que no quiere esperar la vuelta, sino que avanza hacia la gran vendimia en que los enamorados del mundo se sueltan para hacer de la tarea la más completa de las ejecutorias". GONZÁLEZ LARA, José, Molinos y girasoles, Ciudad Real, Caja Rural Provincia, 1982, pág. 22.

23. CERVANTES, Miguel de, El Ingenioso Hidalgo don Quijote de La Mancha. Ilustrado por Gregorio Prieto. Revisión y notas de Federico de Onís y Antonio García de Solalinde, 2 vols., Madrid, Biblioteca Nueva, 1969; 2. ${ }^{\circ}$ ed.: Bilbao, Desclée de Brower, 1976; 3. ${ }^{a}$ ed.: Bilbao, Desclée de Brower, 1980; 4. ${ }^{a}$ ed.: Bilbao, Desclée de Brower, 1984; 5. ${ }^{a}$ ed.: Bilbao, Asuri, 1986. 
amén de un texto introductorio, del que ya hemos hablado, donde el creador manchego emplea una tipografía muy del gusto del artista por estos años, concibiendo las letras mismas como verdaderos ensayos dibujísticos ${ }^{24}$.

El protagonista del presente artículo puso enorme interés en la elaboración de este trabajo por varias razones. En primer lugar, eran muchos los insignes creadores que a lo largo de la historia habían llevado a cabo tal empresa ${ }^{25}$; y en segundo término, se trataba de un Quijote iluminado por un manchego, pero además, un manchego profundo admirador de su tierra, volcando Prieto todo su entusiasmo en la elaboración de unos dibujos destinados al libro que él mismo entendía como quintaesencia del mancheguismo ${ }^{26}$.

Ciertamente, según se acaba de decir, Gregorio Prieto abordada una empresa compleja, difícil, pues sin duda el Quijote y sus aventuras cuentan con una abundante producción artística, lo que ha generado una imagen muy concreta de tal personaje en el imaginario colectivo, algo que era prácticamente imposible transformar, cambiar o innovar. A pesar de lo cual, esta edición de Prieto se convirtió en paradigmática, al establecer un fluido diálogo entre la realidad de La Mancha y la emotividad del pintor; una edición donde vanguardia y tradición se dan la mano en unas composiciones plenas de vida y de fluidez narrativa.

Atendiendo a los antecedentes históricos en la configuración del imaginario artístico del Quijote, lo cierto es que desde muy temprano, el éxito alcanzado por la novela cervantina hizo que se publicaran algunas ediciones ya en el siglo XVII incluyendo sus respectivas ilustraciones. Es de notar en este sentido que tales publicaciones fueron en algunos casos más abundantes allende nuestras fronteras. Este interés bibliográfico por las aventuras del Caballero de la Triste Figura, creció cualitativa y cuantitativamente sobre todo a partir del siglo XVIII. Cómo no recordar, por ejemplo, la edición patrocinada por Lord Carteret en 1738 en Londres, acompañada en este caso por los dibujos del holandés John Vanderbank.

Es también en el siglo de las luces, concretamente en 1780, cuando surge por parte de la Real Academia Española la iniciativa para efectuar una gran edición del Quijote, a la manera de lo que se habían hecho en el extranjero $^{27}$. Esta publicación, que salió de la imprenta de Joaquín de Ibarra, de ahí que se conozca como el Quijote de Ibarra, aunque fuese patrocinada por la Real corporación ya citada, contó con la colaboración de algunos de los más destacados dibujantes de entonces, como José del Castillo o Antonio Carnicero, quienes ofrecerán una imagen del Quijote más ajustada al relato cervantino y, por tanto, alejada de esa tradición sofisticada y rococó que se había acuñado en las publicaciones francesas o británicas.

Pero sin duda, Don Quijote fue un mito por excelencia para los románticos, por tal motivo no resulta extraño que el propio Eugène de Delacroix dedicase alguna obra a Don Alonso Quijano, o que en 1863 viera la luz una de las ediciones más ambiciosas del Quijote, la de Gustave Doré, quien incluso llegó a visitar España en dos ocasiones para realizar unos dibujos fieles al relato cervantino.

\footnotetext{
24. Para el estudio de las ilustraciones del Quijote realizadas por Gregorio Prieto, hay que citar la conferencia titulada Las ilustraciones para el Quijote de Gregorio Prieto de la Profesora Almarcha, con motivo del Congreso Gregorio Prieto en las vanguardias, organizado conjuntamente por las universidades de Turín y Castilla La Mancha en abril de 2005.

25. Para el estudio de la ilustración del Quijote a lo largo de la historia véase: VARELA OLEA, Ma Ángeles y HERNÁNDEZ MIRÓN, Juan Luis (coords.), Huellas de Don Quijote. La presencia cultural de Cervantes, Madrid, Universidad San Pablo CEU, 2005; y BRASAS EGIDO, José Carlos, "El Quijote en la pintura y la ilustración gráfica", Boletín de la Real Academia de Bellas Artes de la Purísima Concepción, n. 30, 2003, págs. 61-79.

26. PRIETO MUÑOZ, Gregorio, Molinos..., op. cit., pág. 24.

27. BLAS BENITO, Javier, MATILLA, José Manuel y MEDRANO, José Miguel, El Quijote ilustrado: modelos de representación en las ediciones españolas del siglo XVIII y comienzos del XIX, Madrid, Fundación Gregorio Prieto, 2005, págs. 15-32.
} 
Mucho se puede añadir a lo dicho en torno a la tradición iconográfica del Quijote previa a Gregorio Prieto, tal son los modelos acuñados por Daumier, Zuloaga, Dalí, Picasso y un largo etcétera.

No obstante, Gregorio Prieto participará de una tendencia evidente en todos los creadores que a lo largo de la pasada centuria dibujaron, pintaron o ilustraron las aventuras del Caballero de la Triste Figura. Dicha querencia se ha singularizado porque los artistas no se han supeditado necesariamente a la identificación literal de los distintos episodios de la novela cervantina, por el contrario, han creado desde su fantasía imágenes mucho más personales ${ }^{28}$.

Atendiendo a tales antecedentes, y en este contexto, Prieto en algunos aspectos se mantendría fiel a cierta tradición y en otros casos será un claro innovador.

No debemos obviar otra dificultad que entraña la ilustración de las andanzas de Don Alonso Quijano; y es que en esta novela solemos contar con dos puntos de vista contrapuestos a partir de un mismo hecho. A saber, la imagen descarnadamente real de Sacho frente a la idealización de Don Quijote. La tradición artística ha optado por un caso u otro, según el grado de atracción narrativa que hayan presentado los respectivos capítulos a plasmar gráficamente.

Caso paradigmático a este respecto es una figura tan importante como Dulcinea. Comparemos esta visión contrastada entre Sancho y Quijote, controversia que ya no sólo se cierne en torno a un hecho, sino en relación a un personaje concreto. En el capítulo XIII de la primera parte de la novela, don Alonso Quijano describe a Vivaldo de esta guisa a su amada Dulcinea:

"Aqui dio un gran suspiro don Quijote y dijo: yo no podré afirmar si la dulce mi enemiga gusta o no de que el mundo sepa que yo la sirvo. Solo sé decir, respondiendo a lo que con tanto comedimiento se me pide, que su nombre es Dulcinea, su patria, el Toboso, un lugar de la Mancha; su calidad por lo menos ha de ser de princesa, pues es Reina y Señora mia; su hermosura, sobrehumana, pues en ella se vienen a hacer verdaderos todos los imposibles y quiméricos atributos de belleza que los poetas dan a sus damas: que sus cabellos son oro, su frente campos elíseos, sus cejas arcos del cielo, sus ojos soles, sus mejillas rosas, sus labios corales, perlas sus dientes, alabastro su cuello, mármol su pecho, marfil sus manos, su blancura nieve, y las partes que a la vista humana encubrió la honestidad son tales, según yo pienso y entiendo, que sólo la discreta consideración puede encarecerlas, y no compararlas" 29 .

¿Cuál es la imagen que de Dulcinea nos ofrece Sancho Panza? La tenemos en el capítulo XXV de esta misma primera parte:

"Bien la conozco - dijo Sancho-y sé decir que tira tan bien una barra como el más forzudo zagal de todo el pueblo. ¡Vive el Dador, que es moza de chapa, hecha y derecha y de pelo en pecho, y que puede sacar la barba del lodo cualquier caballero andante o por andar que le tuviere por señora! ;Oh hideputa, qué rejo tiene, y qué voz! Sé decir que se puso un día encima del campanario de la aldea a llamar unos zagales suyos que andaban en un barbecho de su padre, $y$, aunque estaban de alli más de media legua, asi la oyeron como si estuvieran al pie de la torre. Y lo mejor que tiene es que no es nada melindrosa porque tiene mucho de

28. BRASAS EGIDO, José Carlos, "El Quijote en la pintura...", op. cit., págs. 61-79.

29. CERVANTES, Miguel de, Don Quijote de La Mancha, Barcelona, Instituto Cervantes-Crítica, 1998, págs. $141-142$. 


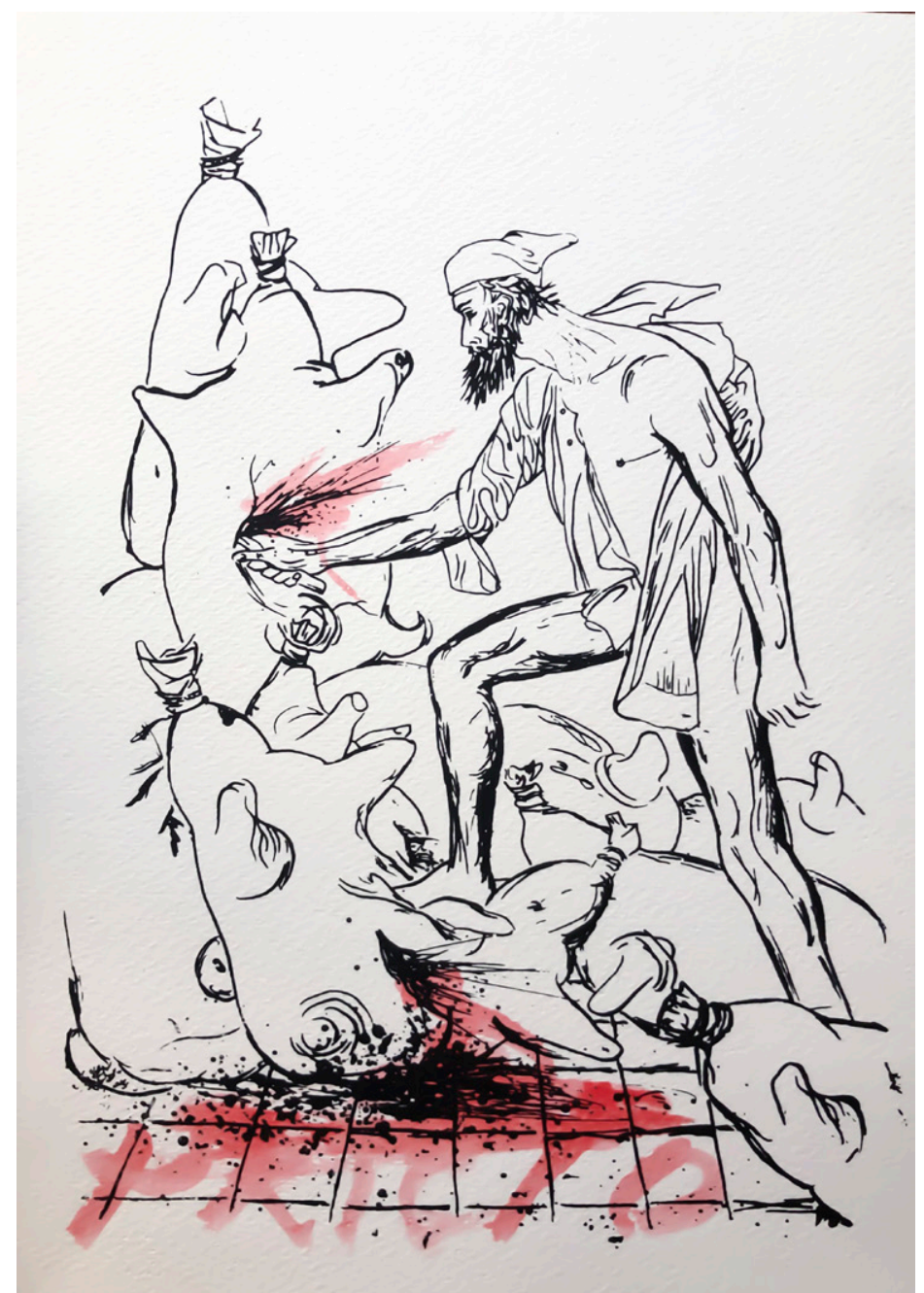

Fig. 6. Gregorio Prieto: Don Quijote lucha con los pellejos de vino (1963), litografía, Fundación Gregorio Prieto. cortesana, con todos se burla y de todo hace mueca y donaire" 30 .

Entre sendas descripciones, Prieto, a la hora de abordar la ilustración correspondiente a Dulcinea, optará por la refinada y nobilísima imagen ofrecida por Don Quijote. En esto el creador manchego se atiene a lo común de otras ediciones ilustradas, donde solemos ver a esa Aldonza Lorenzo refinada y excelsa sońada por Don Alonso Quijano. Aunque no siempre, en esto también hay excepciones, como en el Quijote de Ibarra, donde Antonio Carmona se deleita en esa otra mujer más vulgar y viril que nos describe Sancho ${ }^{31}$.

Prieto recrea el rostro de Dulcinea a partir de una línea deudora especialmente de sus cuadernos de dibujos de los años treinta y cuarenta, como Cuerpos (1931), Matelots (1935) o Students. Oxford \& Cambridge (1938). Notemos cómo en el rostro de la Dulcinea de Gregorio Prieto existe cierta ambigüedad sexual. Ello no es extraño, pues tal concepto recapitula de alguna manera la idea misma de belleza de nuestro pintor, aquella que dimana de los ejemplos clásicos que tanto le marcaron, tal es el caso de la estatuaria en general o del Auriga de Delfos en particular ${ }^{32}$.

Esta tendencia a la ambigüedad como el súmmum de la perfección estética, es perceptible asimismo en la estampa protagonizada por Dorotea, quien no obstante, según se narra en el capítulo XXVIII de la primera parte, fue confundida inicialmente por Don Quijote y el cura con un joven muchacho. Tal confusión permitió a Gregorio Prieto idear un rostro de clara belleza asexuada.

En otros casos, por ejemplo, cuando Prieto da vida al episodio de los molinos, no apreciamos los

30. Ibídem, pág. 283.

31. BLAS BENITO, Javier; MATILLA, José Manuel y MEDRANO, José Miguel, El Quijote ilustrado..., op. cit., págs. 34 y 96.

32. Respecto a los datos concretos de las litografías ejecutadas por Gregorio Prieto para esta edición de El Quijote nos atenemos a la catalogación referencial que de la obra gráfica del artista valdepeñero ha efectuado Óscar Muñoz, recogida en el catálogo de la exposición por él comisariada: Gregorio Prieto: obra gráfica, Valdepeñas, Fundación Gregorio Prieto, 2009, págs. 112-120, 180-185, 187 y 189-190. 
gigantes que veía el Ingenioso Hidalgo, sino que, por el contrario, encontramos esos molinos contra los que prevenía Sancho Panza a su señor. Claro que tratándose de Prieto no cabía otra elección. Recordemos que el pintor manchego fue un incólume defensor de los molinos de viento, recreando con sus pinceles todos los molinos que pudo conocer en tantos lugares como los que vivió, que fueron muchos. A ellos dedicó artículos y libros, de su mano se recuperaron los tan emblemáticos de Consuegra, Mota del Cuervo o se construyeron otros nuevos, como el citado de Argamasilla de Alba.

En esta lucha de Don Quijote contra los molinos, apreciemos cómo el pintor manchego adapta la técnica dibujística al momento relatado. Frente a la línea fluida y delicada que apreciábamos en Dulcinea, en este caso el trazo se torna mucho más rudo y además se completa con ese dripping en tinta tan característico de Prieto a partir de los años cincuenta. En este auténtico bosque de molinos, Don Quijote aparece minimizado, dramatizando así el momento de la caída del protagonista de la novela cervantina.

Según podemos observar, una de las principales aportaciones de esta edición del Quijote es que en ella Gregorio Prieto compendia su amplia técnica dibujística. En este momento el artista era un reconocido dibujante e ilustrador. Desde sus dibujos neocubistas de los años veinte para revistas de vanguardia como Litoral o Gaceta literaria, este artista daría el salto a su personal grafía neoingresca de la mano de la influencia del Picasso neoclásico, donde la línea sería la auténtica protagonista de cuadernos ilustrados ya citados, como Matelots o Students. Oxford \& Cambridge. Paulatinamente, Prieto en los años cincuenta abordaría un tipo de dibujo que de algún modo se convierte en trasunto de la fiereza cromática y táctil de su pintura por entonces, y lo haría a través de un trazo mucho más grueso, del rayado o del empleo del dripping. Este amplio bagaje, que se ha intentado sintetizar, será empleado por nuestro artista para su Quijote según fueran las necesidades descriptivas y narrativas de los personajes o de los capítulos elegidos para su correspondiente ilustración.

Ello se aprecia especialmente si cotejamos la linealidad de Dulcinea con la estampa donde Gregorio plasma la llegada de Don Quijote a El Toboso. Prieto muestra su interés por la textura mediante el rayado y el dripping en tinta de los primeros términos, buscando la sensación de sombra y nocturnidad. Mientras Don Quijote y Sancho aparecen en la parte inferior izquierda de un modo casi imperceptible, confundiéndose sus siluetas con las sombras de los primeros términos, siendo el protagonista real del dibujo el pueblo propiamente dicho, donde destaca especialmente su iglesia parroquial, aquella contra la que el Ingenioso Hidalgo terminó topando cuando intentaba encontrar el supuesto alcázar de su señora y amada Dulcinea.

Por su parte, en la estampa que relata la lucha de Don Alonso Quijano contra los pellejos de vino en pro de la salvación de la princesa Micomicona, Prieto intenta retomar la linealidad de su dibujística más personal. El valdepeñero huye de matices internos o de juegos lumínicos, para valorar la línea en toda su sensualidad poética. Destacable es la fuerza que el autor transmite en esta peculiar batalla, a través sobre todo de la marcada vehemencia de Don Quijote.

Cuando Gregorio Prieto ejecutó los trabajos correspondientes a esta edición del Quijote, el collage había tomado ya carta de naturaleza en su producción artística, pensemos en sus célebres popares, versión castiza y personal del Pop Art norteamericano. Pues bien, el collage también formará parte de esta magna obra. El pintor rompía así con la tradición netamente dibujística y pictórica que a lo largo de la 


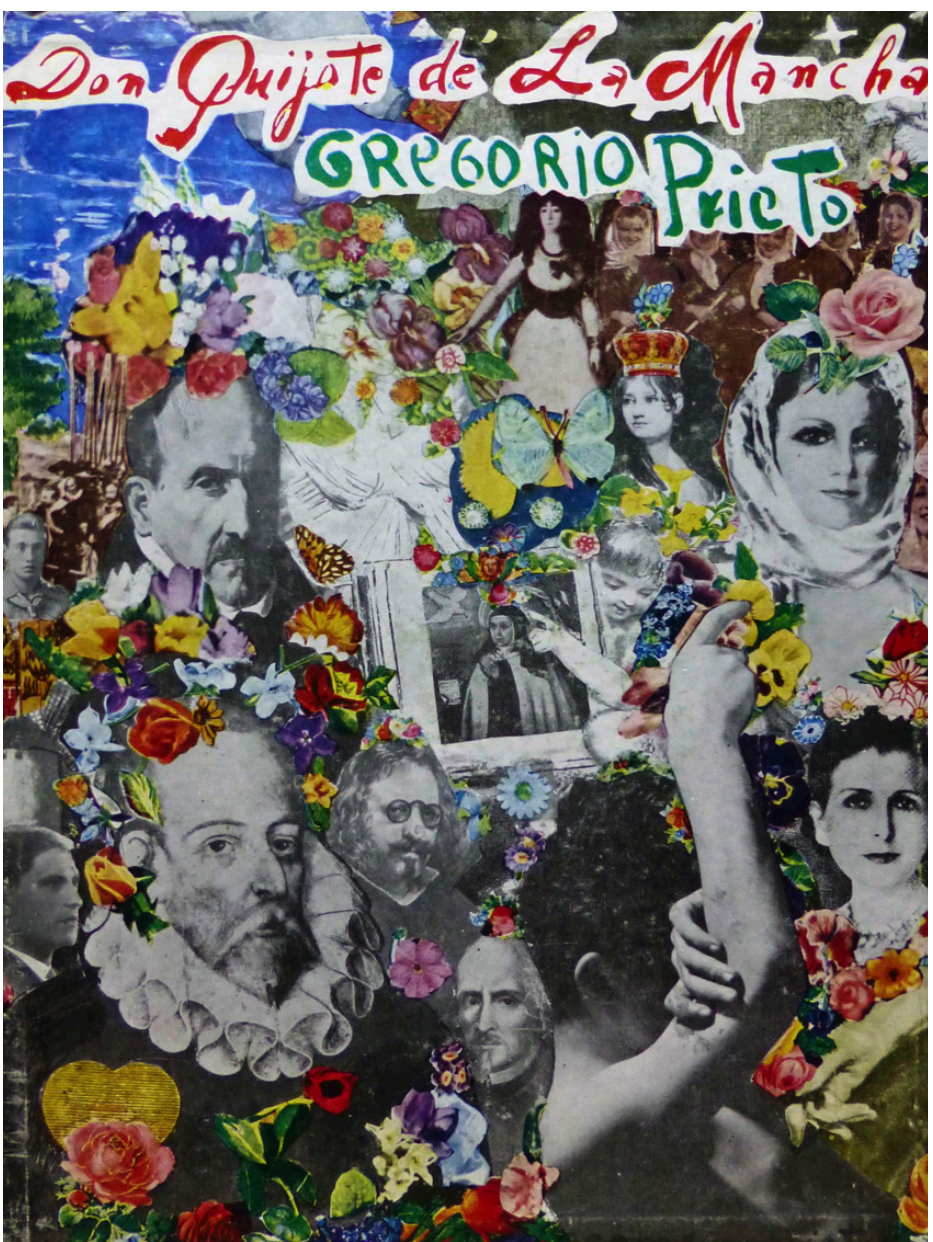

Fig. 7. Gregorio Prieto: Sobrecubierta para la edición del Quijote (1969), collage, Fundación Gregorio Prieto. historia había caracterizado las diferentes versiones ilustradas de las aventuras del célebre Hidalgo.

Según se ha insistido, el pintor valdepeñero cuidó minuciosamente todos y cada uno de los detalles de esta edición, y, por supuesto, a ello no escapó la caja que guardaba los dos volúmenes, ni sus cubiertas. Es aquí precisamente donde se reproducen sendos collages compuestos a partir de fotografías recortadas a las que se añaden llamativas flores a modo de homenaje, pues estos collages se conciben como auténtico tributo a Cervantes. En torno a su efigie se distribuyen los recortes fotográficos de coloridas flores, así como de algunos seres clásicos que con sus instrumentos musicales también celebran al glorioso literato.

Con el fin de no ser reiterativos en el análisis de esta serie de dibujos y litografías, cedamos la palabra a Antonio Manuel Campoy, quien efectuó el siguiente balance a la hora de evaluar el Quijote ilustrado por Gregorio Prieto:

"La versión del Quijote que, lentamente, a través de los años, fue imaginando y realizando Gregorio Prieto, es, cabalmente, la versión pura e ideal de su tierra manchega, y el entendimiento de Alonso Quijano como un modelo de amor. El Quijote es para Gregorio Prieto un libro de amor, pero un libro de amor que únicamente se explica desde, en, por y para La Mancha. A través de imágenes puras de la mancheguidad, sean rosas o muchachas pensativas, rumorosos molinos de viento a los que una brisa mágica empuja a moler flores de azafrán, manos espirituales, nubes y racimos... Cervantes es ahora un misterio en flor, un misterio enamorado, cercado de estrellas y mariposas, humanisimo al mismo tiempo que surreal'33.

Nada más clásico que lo verdaderamente moderno, ni más moderno que lo auténticamente clásico. Esta máxima bien se puede aplicar al conjunto de ilustraciones que Gregorio Prieto efectuó para iluminar una de sus obras más anheladas: El Ingenioso Hidalgo Don Quijote de La Mancha. Tales dibujos, efectuados en un momento avanzado de su trayectoria artística, aglutinaban no sólo su amplia experiencia en el arte gráfico, sino que también recogían un importante componente emotivo respecto a su tierra de origen. Junto

33. CAMPOY, Antonio Manuel, Homenaje de Miguel de Cervantes y Gregorio Prieto a Barcelona, Barcelona, Camarote Granados, 1971. 
a ello, el creador valdepeñero abordó tal empresa desde el conocimiento real de La Mancha combinado con algunas metáforas y composiciones cercanas al surrealismo. Imaginación y realidad, por tanto, se dan la mano precisamente en las ilustraciones de una novela cuyos protagonistas tienen dos formas de ver el mundo: los nobles ideales de Don Quijote y la realidad descarnada de Sancho, ambas concepciones se encarnan perfectamente en el universo imaginario de Gregorio Prieto.

ALBERTI MERELLO, Rafael, La arboleda perdida. Memorias, Barcelona, Seix Barral, 1975.

Bibliografía ALBI, M., "Valdepeñas y sus hijos predilectos", El Sol, 22-IX-1922.

ANÓNIMO, "Los actos en homenaje a Cervantes, en Argamasilla de Alba, resultaron brillantísimos", Lanza, 24-IV-1963.

ANÓNIMO, "Nueva Fundación”, Diez Minutos, 13-III-1968.

ANÓNIMO, “Otra vez Gregorio Prieto", Artes, 23-XII-1963.

ANÓNIMO, "Para desagraviar a Cervantes. El pintor Gregorio Prieto se recluye en la Cueva de Medrano", Informaciones, 28-VIII-1961.

ANÓNIMO, "Una exposición de pintura”, La Libertad, 9-IX-1922.

ANÓNIMO, "Valdepeñas y Gregorio Prieto", El Liberal, 13-IX-1922.

ARROYO, J. F., "Nace la Fundación Gregorio Prieto”, Lanza, 7-III-1968.

BLAS BENITO, Javier; MATILLA, José Manuel y MEDRANO, José Miguel, El Quijote ilustrado: modelos de representación en las ediciones españolas del siglo XVIII y comienzos del XIX, Madrid, Fund. Gregorio Prieto, 2005.

BRASAS EGIDO, José Carlos, "El Quijote en la pintura y la ilustración gráfica”, Boletín de la Real Academia de Bellas Artes de la Purísima Concepción, n. ${ }^{\circ}$ 30, 2003, págs. 61-79.

CAMPOY, Antonio Manuel, Homenaje de Miguel de Cervantes y Gregorio Prieto a Barcelona, Barcelona, Camarote Granados, 1971.

CERVANTES, Miguel de, Don Quijote de La Mancha, Barcelona, Instituto Cervantes-Crítica, 1998.

CERVANTES, Miguel de, El Ingenioso Hidalgo don Quijote de La Mancha. Ilustrado por Gregorio Prieto. Revisión y notas de Federico de Onís y Antonio García de Solalinde, 2 vols., Madrid, Biblioteca Nueva, 1969; 2. ${ }^{\circ}$ ed.: Bilbao, Desclée de Brower, 1976; 3. ${ }^{\mathrm{a}}$ ed.: Bilbao, Desclée de Brower, 1980; 4. ${ }^{\mathrm{a}}$ ed.: Bilbao, Desclée de Brower, 1984; 5.a ed.: Bilbao, Asuri, 1986.

DE MORA, G., "Ayer se constituyó, en Argamasilla de Alba, la Fundación Gregorio Prieto", La vanguardia, 14-III-1968.

Exposición Gregorio Prieto, Madrid, Palacio de Bibliotecas y Museos, 1928.

FERNÁNDEZ ALBA, J., "Don Quijote de La Mancha, libro de amor”, Lanza, 4-VI-1959.

GARCÍA-LUENGO, Javier, "Gregorio Prieto y Valladolid", Boletín de la Real Academia de Bellas Artes de la Purísima Concepción de Valladolid, n. ${ }^{\circ}$ 40, 2005, págs. 159-168.

GARCÍA-LUENGO, Javier, "La primera promoción de la residencia de paisajistas de El Paular", Boletín de la Real Academia de Bellas Artes de la Purísima Concepción de Valladolid, n.o 47, 2012, págs. 115-124.

GARCÍA MORALES, Justo, Conmemoración de las ediciones del Quijote impresas en Argamasilla de Alba con motivo del primer centenario, Madrid, Ministerio de Educación Nacional, 1963.

GONZÁLEZ LARA, José, Molinos y girasoles, Ciudad Real, Caja Rural Provincia, 1982.

HIERRO, José, “Donquijotes, sanmigueles y molinos”, El Alcázar, Madrid, IX-1961. 
In commemoration of the fourth centenary of the birth of Miguel de Cervantes Saavedra, 1547-1616, Londres, The Hispanic and Luso-Brazilian Councils. Canning House, 1947.

LÓPEZ, J., "La Fundación Gregorio Prieto quedó constituida en Argamasilla de Alba", Ya, 13-III-1968.

MONSONÍS MONFORT, Manuel, "La Sala Cervantes de la Biblioteca Nacional”, Ars Longa, n. o 13, 2004, págs. 53-55.

PRIETO MUÑOZ, Gregorio, La Mancha de Don Quijote, Madrid, Ínsula, 1953.

PRIETO MUÑOZ, Gregorio, Molinos, Madrid, Editora Nacional, 1974.

RABOS BALLESTER, S., "Prieto", $A B C$, 28-XI-1963.

RAMÍREZ DE LUCAS, J., "Prieto”, La Estafeta Literaria, 7-XII-1963.

SHAKESPEARE, William, The Sonnets, Londres, Grey Walls Press, 1948.

TORRE FRANCO, J., "Se constituye en Madrid la Fundación Gregorio Prieto", El Español, 6-V-1967.

TRENAS, J., "El regalo estético de Gregorio Prieto", La Vanguardia Española, 24-III-1968.

VARELA OLEA, Ma Ángeles y HERNÁNDEZ MIRÓN, Juan Luis (coords.), Huellas de Don Quijote. La presencia cultural de Cervantes, Madrid, Universidad San Pablo CEU, 2005.

VERA CAMACHO, J. P., "El Quijote más monumental lo está haciendo Gregorio Prieto”, Dígame, 12-III1963.

VILLAREAL, A., "Hoy se inaugura un nuevo molino en La Mancha", Arriba, Madrid, 23-X-1955. 